\title{
ANTI-ARTHRITIC ACTIVITY OF AMARANTHUS ROXBURGHIANUS NEVSKI HYDROALCOHOLIC AREAL PLANT EXTRACT IN ACUTE AND CHRONIC MODELS IN ALBINO WISTAR RATS
}

\author{
SARAVANAKUMAR K ${ }^{1}$, RADHIKA CHIKATIPALLI ${ }^{2 *}$, CHANDRA SEKHAR KOTHAPALLI BONNOTH ${ }^{3}$ \\ ${ }^{1}$ Department of Pharmaceutics, Sree Vidyanikethan College of Pharmacy, A. Rangampet, Tirupati, Andhra Pradesh, India. ${ }^{2}$ Research \\ Scholar, Pharmaceutical Sciences, Jawaharlal Nehru Technological University, Ananthapur, Andhra Pradesh, India. ${ }^{3}$ Department of \\ Chemistry, Krishna University, Machilipatnam, Andhra Pradesh, India. Email: radhikapharma11@gmail.com
}

Received: 31 January 2020, Revised and Accepted: 12 April 2020

ABSTRACT

Objective: Evaluation of anti-arthritic activity of hydroalcoholic extract of Amaranthus roxburghianus Nevski aerial parts in albino Wistar rats.

Materials and Methods: A. roxburghianus dried aerial parts were extracted with ethyl alcohol: water (70:30) ratio, respectively, by the hot Soxhlet method. Hydroalcoholic A. roxburghianus extract (HARE) was further concentrated to obtain a semisolid residue. Two doses $200 \mathrm{and} 400 \mathrm{mg} / \mathrm{kg}$ of HARE were tested against formaldehyde-induced acute non-immunological and Freund's complete adjuvant (FCA)-induced chronic immunological arthritis in albino Wistar rats. Arthritis assessment was done by morphological studies (paw volume, paw diameter, and body wt.) and hematological parameters radiological, histopathological, and organ wt. studies were also done on the $28^{\text {th }}$ day after animals were sacrificed.

Results: Dose-dependent and significant inhibition of edema were observed in both acute as well as chronic models. The extract at dose $400 \mathrm{mg} / \mathrm{kg}$ showed most potent and significant $(\mathrm{p}<0.05)$ paw edema inhibition which is supported by the results of paw volume and diameter, hematological parameters, in FCA-induced arthritis model. Treatment with HARE also decreased the histopathological alterations induced by FCA model.

Conclusion: HARE protects synovial membrane by improving the health status exhibits promising anti-arthritic activity. This finding thus supports the traditional use of A. roxburghianus for arthritis. However, further studies are needed to carry out the isolation of active constituents of the fraction responsible for the activity.

Keywords: Amaranthus roxburghianus, Freund's complete adjuvant-induced arthritis, Formaldehyde-induced arthritis, Morphological, Hematological, Radiological, Histopathological and organ wt. studies.

(C) 2020 The Authors. Published by Innovare Academic Sciences Pvt Ltd. This is an open access article under the CC BY license (http://creativecommons. org/licenses/by/4. 0/) DOI: http://dx.doi.org/10.22159/ajpcr.2020.v13i6.36994

\section{INTRODUCTION}

Rheumatoid arthritis (RA) is a systemic autoimmune multisystem disease characterized by pain, synovial membrane inflammation, peripheral joint inflammation, morning stiffness, destruction of articular tissues, and restricted joint movement [1-3]. The pathology and etiology of RA are complex and unknown. Destructive changes in the cartilage and bone and outgrowths of bones restrict the mobility of the joints [4]. Arthritis can cause severe disability and ultimately affects a person's ability to carry out everyday tasks, restricts the quality of life, and causes premature death [5]. RA is the most common inflammatory disorder affecting about $1 \%$ of the global adult population; females are three times more prone to RA than males [6-8]. Conventional treatment of RA with NSAIDs, corticosteroids, immune suppressants, and anti-rheumatic drugs tumor necrosis factor (TNF-a and monoclonal antibodies) have limitations [9-11]. Chronic treatment with above agents produces serious adverse effects such as GIT ulcers, cardiovascular, hematological, and renal toxicities $[12,13]$. Patients suffering from chronic autoimmune disorders are advised for alternative methods for symptomatic relief $[14,15]$. Amaranthus roxburghianus Nevski (Family: Amaranthaceae) is a wild plant whose leaves and tender shoots and can be edible and are commonly used as a leafy vegetable [16]. It is commonly known as chiri kura in Telugu language and is used as an abortifacient by tribes of Chittoor district, Andhra Pradesh state of India [17]. Used as iron tonic [18], its extracts or herbal formulations are rich in alkaloids, used in traditional Chinese and Ayurvedic medicine [19]. Its root extract in combination with piperine is used in the effective treatment of inflammatory bowel disease [20]. Further consumption of its leaves is reported for the treatment of sunstroke and urinary disorders [21]. Hence, we attempted to investigate the anti-arthritic effect of hydroalcoholic areal plant extract of A. roxburghianus in acute and chronic models in albino Wistar rats, to prove its importance in the treatment of rheumatism.

\section{MATERIALS AND METHODS}

\section{Plant collection and authentication}

A. roxburghianus plants were purchased as leafy vegetables from the local market of Pileru, Chittoor District, Andhra Pradesh state of India in March 2017; photograph of which is shown in Fig. 1. Authentication of plant was carried out by Dr. K. Madava Chetty, Asst. Professor, Dept. of Botany, Shri Venkateswara University, Tirupati, A.P., India. A voucher specimen of the plant (Ref. No. 1656), dated 11/09/2017, has been preserved there for future references.

\section{Extract preparation}

The aerial plants were obtained by cutting the root portions and thoroughly washed with tap water, and air dried in the shade, powdered in grinder, and passed through \# Sieve No. 40 (ASTM). The dried powder was defatted by petroleum ether and then successive extraction was done with ethyl alcohol:water with $(70: 30)$ ratio, respectively, by the hot Soxhlet method. The hydroalcoholic extract was concentrated in a rotary evaporator (Heidolph Instruments, Laborota 4000, Germany) under reduced pressure. The dried crude hydroalcoholic A. roxburghianus extract (HARE) was collected and preserved in an airtight glass container at $4-8^{\circ} \mathrm{C}$ until final use.

\section{Experimental animals}

Male rats of albino Wistar strain weighing between 180 and $200 \mathrm{~g}$ were used for the experiments. All the animals were obtained from Sree 




Fig. 1: Photograph of Amaranthus roxburghianus Nevski

Venkateshwara Enterprises, Bengaluru, India. All the protocols of animal experiments were approved by the Institutional Animal Ethics Committee of Sree Vidyanikethan College of Pharmacy, Tirupati, Chittoor Dist., A.P., India (Approval No.: SVCP/IAEC/I-001/2018-19 dated on 01/04/2019) in accordance to the guidelines of Committee for the Purpose of Control and Supervision of Experiments on Animals, Ministry of Social Justice and Empowerment, Govt. of India, New Delhi. The animals were housed in polypropylene cages and maintained at $24^{\circ} \mathrm{C} \pm 2^{\circ} \mathrm{C}$ under $12 \mathrm{~h} \mathrm{light/}$ dark cycle and were feeded with standard pellet diet and had free access to water. The animals were given a standard diet supplied by Sree Venkateshwara Enterprises, Bengaluru, India. The composition of the diet is energy $3615(\mathrm{kcal} / \mathrm{kg})$, crude protein $22.05 \%$, crude oil $4.5 \%$, crude fiber $4.10 \%$, ash $11.10 \%$, and sand silica $0.75 \%$.

\section{Experimental design}

A total of 30 male albino Wistar rats weighing 180-200 g were selected and allocated to five groups of six rats in each group $(n=6)$. Group I was used as normal control. Group 2-5 were RA-induced and treated for Freund's complete adjuvant (FCA)-induced arthritis and similarly for formaldehyde-induced arthritis, as given in Table 1.

\section{Dose selection}

Acute toxicity studies were not conducted on the HARE as its safety up to $2000 \mathrm{mg} / \mathrm{kg}$ has been reported in an earlier study [19]. The two doses 200 and $400 \mathrm{mg} / \mathrm{kg}$ were selected based on earlier studies which have reported better response at doses above $400 \mathrm{mg} / \mathrm{kg}$ regarding analgesic and nephroprotective activities [20,21].

\section{Evaluation of anti-arthritic activity}

FCA-induced arthritic rats

FCA contains heat-killed dead Mycobacterium tuberculosis bacteria in liquid paraffin in a concentration of $10 \mathrm{mg} / \mathrm{mL}$. All the rats, except those in the normal control group, were injected intradermally with $0.1 \mathrm{~mL}$ of FCA into the left hind paw on day "0." An interval of 7 days was given for arthritis to develop. All the animals developed the signs of arthritis such as swelling, redness, and restricted movement during this period [22]. The treatment was ended on day 28.

\section{Morphological studies}

Paw volume and diameter studies

Paw volume and paw thickness of rats were measured once in 7 days from day "0" to " 28 " by using Plethysmometer (UGO Basile, Italy 7140) and Vernier caliper respectively.

Body wt. studies

Body weight was measured by electronic balance (Shimadzu C054E032S, Japan) before and after induction and the mean difference in the body wt. was reported.
Table 1: Experimental design

\begin{tabular}{ll}
\hline Group & Treatment \\
\hline Group 1 & Normal control \\
Group 2 & Arthritis control \\
Group 3 & Diclofenac $10 \mathrm{mg} / \mathrm{kg}$ \\
Group 4 & HARE $200 \mathrm{mg} / \mathrm{kg}$ \\
Group 5 & HARE $400 \mathrm{mg} / \mathrm{kg}$ \\
\hline HARE: Hydroalcoholic Amaranthus roxburghianus extract
\end{tabular}

HARE: Hydroalcoholic Amaranthus roxburghianus extract

Hematological studies

Three milliliter blood samples was collected by retro-orbital puncture on $28^{\text {th }}$ day; for the estimation of serum parameters (serum glutamate oxaloacetate transferase [SGOT], serum glutamic pyruvic transferase [SGPT], alkaline phosphatase [ALP], and total protein) and blood parameters (erythrocyte sedimentation rate [ESR] and \%HB) by various diagnostic kits and standard procedures.

Later, rats were sacrificed with a high dose of halothane on $28^{\text {th }}$ day and the ankle joints were used for further radiological, histological, and organ wt. studies.

Radiological studies

On the $28^{\text {th }}$ day, X-ray images (Siemens, Heliophos D X-ray machine) of the hind limbs were taken and the changes at joints were assessed based on joint space and soft tissue swelling.

Histopathological studies

On the $28^{\text {th }}$ day, ankle joints were removed and fixed in $10 \%$ buffered formalin. The bones were decalcified in 5\% formic acid, processed for paraffin embedding, sectioned at $5 \mu \mathrm{m}$ thickness, and subsequently stained with hematoxylin-eosin for examination under a light microscope for the presence of changes in synovium, cartilage, and joint space.

Organs wt. studies

On the $28^{\text {th }}$ day, the spleen and thymus were removed, and weight of the organs were recorded and corrected for $100 \mathrm{~g}$ body wt.

\section{Formaldehyde-induced arthritic rats}

Rats were injected with $0.1 \mathrm{~mL}$ of $2 \% \mathrm{v} / \mathrm{v}$ of formaldehyde solution in the plantar surface of the left foot, on the $1^{\text {st }}$ and $3^{\text {rd }}$ day of the test. Drug treatment was started from the initial day, i.e., from the day of formaldehyde injection ( 0 day) and continued until the $10^{\text {th }}$ day. The rat paw volume was recorded daily by using Plethysmometer (UGO Basile 7140, Italy) [23].

\section{Statistical analysis}

The values were expressed as mean \pm SEM $(n=6)$. The statistical significance was assessed using student t-test or one-way analysis of variance (ANOVA) followed by Dunnett's test and $\mathrm{p}<0.05, \mathrm{p}<0.01$, and $\mathrm{p}<0.001$ were considered to be statistically significant.

\section{RESULTS}

\section{FCA-induced arthritic rats}

Morphological studies

Paw volume and diameter studies

Effect of HARE on paw volume and diameter in FCA-induced arthritic rats was tabulated in Table 2. Challenge with FCA $(0.1 \mathrm{~mL})$ shows the development of paw edema which reached peak edema on the $21^{\text {st }}$ day of injection. Diclofenac treated group shows significant inhibition of paw edema on day $7^{\text {th }}(\mathrm{p}<0.05), 14^{\text {th }}(\mathrm{p}<0.01), 21^{\text {st }}(\mathrm{p}<0.001)$, and day $28^{\text {th }}(\mathrm{p}<0.001)$. HARE $(200 \mathrm{mg} / \mathrm{kg})$ shows significant inhibition of paw edema on day $21^{\text {st }}$ and day $28^{\text {th }}$ with $(\mathrm{p}<0.01)$. Furthermore, rats treated with HARE $(400 \mathrm{mg} / \mathrm{kg}$ ) show significant inhibition of paw edema on day $7^{\text {th }}(\mathrm{p}<0.05), 14^{\text {th }}(\mathrm{p}<0.05), 21^{\text {st }}(\mathrm{p}<0.01)$, and day $28^{\text {th }}(\mathrm{p}<0.01)$. Paw diameter was increased up to $21^{\text {st }}$ day of adjuvant induction and after that it slightly decreased. Diclofenac treated group shows significant 
Table 2: Effect of HARE on paw volume and diameter in Freund's complete adjuvant-induced arthritic rats

\begin{tabular}{|c|c|c|c|c|c|}
\hline \multirow[t]{2}{*}{ Groups } & \multicolumn{5}{|c|}{ Paw volume (mL) } \\
\hline & Day 0 & Day 7 & Day 14 & Day 21 & Day 28 \\
\hline Normal control & $0.16 \pm 0.03$ & $0.16 \pm 0.02$ & $0.16 \pm 0.04$ & $0.17 \pm 0.03$ & $0.17 \pm 0.01$ \\
\hline Diclofenac 10 mg/kg & $0.93 \pm 0.06$ & $1.94 \pm 0.10^{*}$ & $1.86 \pm 0.11^{* *}$ & $1.58 \pm 0.11^{* * *}$ & $1.45 \pm 0.11^{* * *}$ \\
\hline HARE 200 mg/kg & $0.90 \pm 0.07$ & $1.41 \pm 0.10$ & $2.18 \pm 0.12$ & $1.92 \pm 0.17^{* *}$ & $1.88 \pm 0.13^{* *}$ \\
\hline HARE $400 \mathrm{mg} / \mathrm{kg}$ & $0.92 \pm 0.06$ & $1.98 \pm 0.11^{*}$ & $1.89 \pm 0.09 *$ & $1.77 \pm 0.19^{* *}$ & $1.68 \pm 0.16^{* *}$ \\
\hline Groups & Day 0 & Day 7 & Day 14 & Day 21 & Day 28 \\
\hline Normal control & $0.34 \pm 0.16$ & $0.33 \pm 0.13$ & $0.34 \pm 0.12$ & $0.35 \pm 0.14$ & $0.35 \pm 0.12$ \\
\hline Arthritis control & $8.00 \pm 0.11$ & $15.00 \pm 0.24$ & $20.00 \pm 0.33$ & $23.00 \pm 0.10$ & $21.00 \pm 0.51$ \\
\hline Diclofenac 10 mg/kg & $7.32 \pm 0.13$ & $13.42 \pm 0.37$ & $13.02 \pm 0.12^{* *}$ & $12.86 \pm 0.23^{* * *}$ & $12.00 \pm 0.22^{* * *}$ \\
\hline HARE $200 \mathrm{mg} / \mathrm{kg}$ & $9 \pm 0.15$ & $13.47 \pm 0.45$ & $18.67 \pm 0.74$ & $17.12 \pm 0.09 * *$ & $16 \pm 0.36^{* *}$ \\
\hline HARE $400 \mathrm{mg} / \mathrm{kg}$ & $8.43 \pm 0.20$ & $13.09 \pm 0.13$ & $17.02 \pm 0.56$ & $16 \pm 0.10^{* *}$ & $15 \pm 0.11^{* *}$ \\
\hline
\end{tabular}

Values are expressed as mean \pm SEM $(n=6) .{ }^{*} \mathrm{p}<0.05,{ }^{* *} \mathrm{p}<0.01,{ }^{* * *} \mathrm{p}<0.001$ as compared with control (one-way ANOVA followed by Dunnet's test). HARE: Hydroalcoholic Amaranthus roxburghianus extract

Table 3: Effect of HARE on body wt. in Freund's complete adjuvant-induced arthritic rats

\begin{tabular}{llll}
\hline Groups & \multicolumn{2}{l}{ Mean body wt. (g) } & $\begin{array}{l}\text { Mean } \\
\text { difference in } \\
\text { body wt }\end{array}$ \\
\cline { 2 - 4 } & $\begin{array}{l}\text { Before } \\
\text { induction }\end{array}$ & $\begin{array}{l}\text { After } \\
\text { induction }\end{array}$ & \\
\hline Normal control & $179 \pm 1.23$ & $179 \pm 1.23$ & - \\
Arthritis control & $165 \pm 3.13$ & $176 \pm 2.4$ & $11 \pm 1.26$ \\
Diclofenac $10 \mathrm{mg} / \mathrm{kg}$ & $173 \pm 2.24$ & $218 \pm 1.38$ & $45 \pm 1.11^{* *}$ \\
HARE $200 \mathrm{mg} / \mathrm{kg}$ & $170 \pm 1.12$ & $202 \pm 3.21$ & $32 \pm 2.03^{*}$ \\
HARE $400 \mathrm{mg} / \mathrm{kg}$ & $181.34 \pm 3.65$ & $217 \pm 5.01$ & $36 \pm 1.67^{*}$ \\
\hline
\end{tabular}

Values are expressed as mean \pm SEM $(n=6) ;{ }^{*} p<0.05,{ }^{* *} \mathrm{p}<0.01$

as compared with control followed by student's t-test.

HARE: Hydroalcoholic Amaranthus roxburghianus extract

inhibition of paw diameter on day $14^{\text {th }}(\mathrm{p}<0.01), 21^{\text {st }}(\mathrm{p}<0.001)$, and day $28^{\text {th }}(\mathrm{p}<0.001)$. HARE $(200 \mathrm{mg} / \mathrm{kg})$ shows significant inhibition of paw diameter on day $21^{\text {st }}$ and day $28^{\text {th }}$ with $(\mathrm{p}<0.01)$. Furthermore, rats treated with HARE $(400 \mathrm{mg} / \mathrm{kg}$ ) show significant inhibition of paw diameter on day $21^{\text {st }}$ and day $28^{\text {th }}(\mathrm{p}<0.01)$. Morphological observation of the rat paws was shown in Fig. 2.

Body wt. studies

Effect of HARE on body wt. in FCA-induced arthritic rats was tabulated in Table 3 indicates the increased body wt. during the treatment of standard drug and HARE.

\section{Hematological studies}

Effect of HARE on various serum and blood parameters in FCA-induced arthritic rats was tabulated in Table 4 . Challenge with CFA $(0.1 \mathrm{~mL})$ shows an increased in level of SGOT, SGPT, ALP, and decreased in level of total protein in the control group. Diclofenac treated group shows decreased in level of SGOT ( $p<0.01)$, SGPT ( $p<0.01)$, ALP $(p<0.001)$, and increased in level of total protein $(\mathrm{p}<0.01)$. HARE $(200 \mathrm{mg} / \mathrm{kg})$ shows significantly decreased in level of SGPT $(\mathrm{p}<0.05)$, ALP $(\mathrm{p}<0.05)$, and increased in level of total protein $(\mathrm{p}<0.05)$. HARE $(400 \mathrm{mg} / \mathrm{kg})$ treated group shows decreased in level of SGOT $(\mathrm{p}<0.05)$, SGPT $(\mathrm{p}<0.05)$, ALP $(p<0.01)$, and increased in level of total protein $(p<0.05)$.

\section{Radiological studies}

Radiological observations of the rat hind limbs were shown in Fig. 3. Arthritis control joint showed soft tissue swelling and narrowing of joint space. The joint space was intact and soft tissue swelling was reduced in rats treated with diclofenac (10 mg/kg), HARE (200 mg/kg), and HARE ( $400 \mathrm{mg} / \mathrm{kg}$ ), as seen in Fig. 3.



Fig. 2: Morphological observations of the rat paws (a) normal control (b) arthritis control (c) diclofenac (10 mg/kg)

(d) hydroalcoholic Amaranthus roxburghianus extract (HARE) $(200 \mathrm{mg} / \mathrm{kg})(\mathrm{e})$ HARE $(400 \mathrm{mg} / \mathrm{kg})$ treated rats



Fig. 3: Radiological observation of the rat hind limbs (a) normal control (b) arthritis control (c) diclofenac $(10 \mathrm{mg} / \mathrm{kg})$ (d) hydroalcoholic Amaranthus roxburghianus extract (HARE) $(200 \mathrm{mg} / \mathrm{kg})(\mathrm{e})$ HARE $(400 \mathrm{mg} / \mathrm{kg})$ treated rats 
Table 4: Effect of HARE on hematological parameters in Freund's complete adjuvant-induced arthritic rats

\begin{tabular}{|c|c|c|c|c|c|c|}
\hline \multirow[t]{2}{*}{ Groups } & \multicolumn{4}{|c|}{ Serum parameters } & \multicolumn{2}{|c|}{ Blood parameters } \\
\hline & SGOT (IU/L) & SGPT (IU/L) & ALP (IU/L) & Total protein $(\mathrm{g} / \mathrm{dl})$ & ESR (mm/hr) & HB (g \%) \\
\hline Normal control & $126.50 \pm 1.38$ & $62.75 \pm 1.70$ & $142.35 \pm 1.25$ & $7.95 \pm 0.11$ & $13.17 \pm 1.35$ & $17.33 \pm 0.76$ \\
\hline Arthritis control & $100.27 \pm 13.01$ & $70.26 \pm 1.87$ & $268.36 \pm 20.13$ & $3.02 \pm 0.22$ & $35.3 \pm 5.4$ & $7.5 \pm 0.6$ \\
\hline Diclofenac $10 \mathrm{mg} / \mathrm{kg}$ & $51.32 \pm 6.55^{* *}$ & $47.08 \pm 2.14^{* *}$ & $140.65 \pm 16.27^{* * *}$ & $7.93 \pm 0.10^{* *}$ & $16.47 \pm .6 .04^{* *}$ & $13.3 \pm 1.01^{* *}$ \\
\hline HARE $200 \mathrm{mg} / \mathrm{kg}$ & $75 \pm 8.81$ & $53.48 \pm 1.30^{*}$ & $198.81 \pm 13.44^{*}$ & $6.84 \pm 0.45^{*}$ & $25.36 \pm 7.12$ & $11.2 \pm 0.9^{* *}$ \\
\hline HARE $400 \mathrm{mg} / \mathrm{kg}$ & $67.93 \pm 4.41^{*}$ & $51.63 \pm 4.35^{*}$ & $172.18 \pm 10.68^{* *}$ & $6.96 \pm .11^{*}$ & $19.2 \pm 10.21^{*}$ & $12.4 \pm 1.11^{* *}$ \\
\hline
\end{tabular}

Values are expressed as mean \pm SEM $(\mathrm{n}=6) .{ }^{*} \mathrm{p}<0.05,{ }^{* *} \mathrm{p}<0.01,{ }^{* * *} \mathrm{p}<0.001$ as compared with control (one-way ANOVA followed by Dunnet's test). HARE: Hydroalcoholic Amaranthus roxburghianus extract

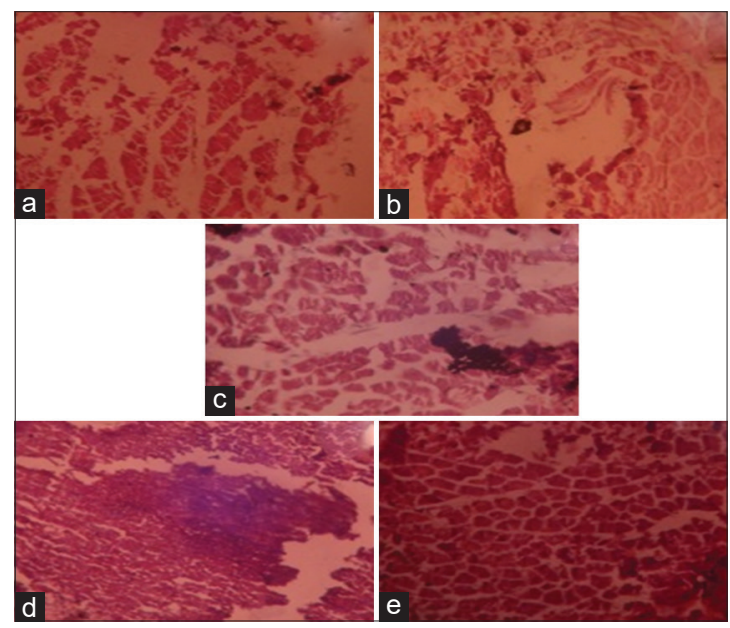

Fig. 4: Histopathological observation of the rat ankle tissues (a) normal control (b) arthritis control (c) diclofenac $(10 \mathrm{mg} / \mathrm{kg})$ (d) hydroalcoholic Amaranthus roxburghianus extract (HARE) $(200 \mathrm{mg} / \mathrm{kg})(\mathrm{e}) \mathrm{HARE}(400 \mathrm{mg} / \mathrm{kg})$ treated rats. Magnification: $\times 100$; thickness: $5 \mu \mathrm{m}$

Histopathological studies

Histopathological observations of the rat ankle joint tissues were shown in Fig. 4 indicate that show destructive lesions in connective tissue, vascularity into joint space, and granuloma formation in the arthritis control group. There was normal connective tissue structure with the absence of necrosis in the ankle joint of the normal control group. Diclofenac treatment showed normal connective tissue of ankle joint with the presence of lesser edema and absence of necrosis. HAREtreated rats produced knee joint protection compared to arthritis control group rats by reducing the inflammation and necrosis. Rats treated with HARE $(200 \mathrm{mg} / \mathrm{kg})$ showed granuloma formation along with edema and necrosis with few inflammatory cells. Rats treated with EABP $(400 \mathrm{mg} / \mathrm{kg}$ ) showed mild necrosis with edema, but granuloma was absent in ankle joint.

Organs wt. studies

There was a decrease in thymus wt. whereas the mean spleen wt. was increased in the FCA treated rats as compared to the NC group (Table 5). A rise in spleen wt. was significantly $(\mathrm{p}<0.01)$ inhibited in rats treated with HARE $(200$ and $400 \mathrm{mg} / \mathrm{kg})$ and diclofenac $(10 \mathrm{mg} / \mathrm{kg})$ as compared to FCA treated rats. Only treatment with dose $400 \mathrm{mg} / \mathrm{kg}$ of HARE and diclofenac attenuated the decreased wt. of the thymus, significantly $(\mathrm{p}<0.01)$.

\section{Formaldehyde-induced arthritic rats}

Effect of HARE on paw volume in formaldehyde-induced arthritic rats was tabulated in Table 6. Sub-planter injection of $0.1 \mathrm{~mL}$ of $2 \% \mathrm{v} / \mathrm{v}$ formaldehyde shows increased in paw edema which reaches a peak on day $6^{\text {th }}$ and after that it slightly decreased on day $10^{\text {th }}$. Diclofenac $(10 \mathrm{mg} / \mathrm{kg})$ treated rat shows significant changes in paw edema on the day $3^{\text {rd }}(\mathrm{p}<0.05)$, day $6^{\text {th }}(\mathrm{p}<0.001)$, and day $10^{\text {th }}(\mathrm{p}<0.001)$.
Table 5: Effect of HARE on thymus and spleen wt. in Freund's complete adjuvant-induced arthritic rats

\begin{tabular}{lll}
\hline Groups & $\begin{array}{l}\text { Spleen wt. } \\
\text { (mg/100 g b.wt.) }\end{array}$ & $\begin{array}{l}\text { Thymus wt. } \\
\text { (mg/100 g b.wt.) }\end{array}$ \\
\hline Normal control & $185.5 \pm 4.09$ & $103.5 \pm 2.01$ \\
Arthritis control & $249.16 \pm 2.71$ & $81.00 \pm 0.81$ \\
Diclofenac $10 \mathrm{mg} / \mathrm{kg}$ & $209.83 \pm 4.20^{* *}$ & $91.00 \pm 0.96^{* *}$ \\
HARE $200 \mathrm{mg} / \mathrm{kg}$ & $231.50 \pm 1.56^{* *}$ & $84.50 \pm 0.76$ \\
HARE $400 \mathrm{mg} / \mathrm{kg}$ & $212.00 \pm 1.06^{* *}$ & $89.50 \pm 1.33^{* *}$ \\
\hline
\end{tabular}

Values are expressed as the mean \pm SEM $(n=6) ;{ }^{*}<0.05,{ }^{* *} \mathrm{p}<0.01$ as compared with control (one-way ANOVA followed by Dunnet's test). HARE: Hydroalcoholic Amaranthus roxburghianus extract

Table 6: Effect of HARE on paw volume in formaldehyde-induced arthritic rats

\begin{tabular}{lllll}
\hline Groups & \multicolumn{2}{l}{ Paw volume $(\mathrm{mL})$} & \\
\cline { 2 - 5 } & Day 0 & Day 3 & Day 6 & Day 10 \\
\hline $\begin{array}{l}\text { Normal } \\
\text { control }\end{array}$ & $0.16 \pm 0.03$ & $0.16 \pm 0.02$ & $0.16 \pm 0.04$ & $0.17 \pm 0.03$ \\
$\begin{array}{l}\text { Arthritis } \\
\text { control }\end{array}$ & $0.92 \pm 0.09$ & $1.48 \pm 0.32$ & $1.97 \pm 0.44$ & $1.75 \pm 0.21$ \\
$\begin{array}{l}\text { Diclofenac } \\
10 \text { mg/kg }\end{array}$ & $0.90 \pm 0.03$ & $1.22 \pm 0.24^{* * *}$ & $1.19 \pm 0.13^{*}$ & $1.09 \pm 0.27^{* * *}$ \\
$\begin{array}{l}\text { HARE 200 } \\
\text { mg/kg }\end{array}$ & $0.94 \pm 0.11$ & $1.59 \pm 0.21^{*}$ & $1.36 \pm 0.20$ & $1.23 \pm 0.42^{* *}$ \\
$\begin{array}{l}\text { HARE 400 } \\
\text { mg/kg }\end{array}$ & $0.91 \pm 0.09$ & $1.43 \pm 0.19^{* *}$ & $1.41 \pm 0.31$ & $1.21 \pm 0.22^{* *}$ \\
\hline $\begin{array}{l}\text { Values are } \\
\text { expressed }\end{array}$ & & & & \\
\hline
\end{tabular}

Values are expressed as mean $\pm \operatorname{SEM}(\mathrm{n}=6) .{ }^{*} \mathrm{p}<0.05,{ }^{* *} \mathrm{p}<0.01,{ }^{* * *} \mathrm{p}<0.001$ as compared with control (one-way ANOVA followed by Dunnet's test).

HARE: Hydroalcoholic Amaranthus roxburghianus extract

HARE $(200 \mathrm{mg} / \mathrm{kg}$ ) shows significant changes in paw edema on day $6^{\text {th }}(\mathrm{p}<0.05)$ and day $10^{\text {th }}(\mathrm{p}<0.01)$. Furthermore, rats treated with HARE $(400 \mathrm{mg} / \mathrm{kg}$ ) show significant changes in paw edema on day $6^{\text {th }}(\mathrm{p}<0.01)$ and day $10^{\text {th }}(\mathrm{p}<0.001)$.

\section{DISCUSSION}

The FCA-induced arthritis model in rats is the most common model. This preclinical model predicted the activities of a number of compounds that are currently used in the treatment of RA are being tested in clinical trials. The basis on biochemical parameters, the 4 phases of arthritis, Phase 1: Acute local inflammation of liver and systemic effects (1-4 days); Phase 2: Remission of acute inflammation and periarthritis (7-12 days); Phase 3: Chronic inflammation, periarthritis and osteogenic activity (12-28 days); and Phase 4: Permanent articular deformity and minimal inflammation (35 days onward) [9]. The present study was carried out to see the efficiency of hydroalcoholic extract of aerial parts of indigenous herb, A. roxburghianus against arthritis. In the present study, male Wistar strain rats were selected to induce arthritis because they develop a chronic swelling in multiple joints due to the accumulation of inflammatory cells, erosion of joint cartilage, and bone destruction. 
It has close similarities to human rheumatoid diseases [1]. The determination of paw swelling is apparently simple, sensitive, and quick procedure for evaluating the degree of inflammation and the therapeutic effects of drugs. The Freund's adjuvant model is chosen as it develops chronic swelling in multiple joints with the influence of inflammatory cells with erosion of joint cartilage and bone destruction. Chronic inflammation involves the release of the number of mediators such as cytokines (interleukin-1B and TNF-alpha), granulocyte macrophagecolony stimulating factor, interferon's, and PGDF. These mediators are responsible for the pain, destruction of bone, and cartilage that can lead to severe disability [14]. However, standard drug and HARE extract can significantly suppress the swelling of the paws and also decreases the paw volume in both acute and chronic phase which may be due to the suppression of inflammatory mediators released due to induction of Freund's adjuvant. Although the actual mechanism of suppressing inflammation is not known, it can be correlated with the presence of alkaloids and flavonoids in suppressing the inflammation and antioxidant activity. As the incidence and severity of arthritis increased, the changes in the body weights of the rats also occurred during the course of the experimental period. Earlier findings suggest that absorption of $14^{\circ} \mathrm{C}$-glucose and $14^{\circ} \mathrm{C}$-leucine in rat's intestine was reduced in the case of inflamed rats [24]; but on the treatment with anti-inflammatory drugs, the decrease in absorption was nullified and it shows that the anti-inflammatory drugs correct the decreased/deranged absorption capacity of intestine during inflammation. The increased body weight during the treatment of standard drug, HARE extract, may be due to the restoration of the absorption capacity of intestine. The extract also shows a significant effect on various blood and serum parameters. Formaldehyde-induced arthritis is one of the most commonly used acute model for assessing anti-arthritic potential of plant extracts. The development of edema in the paw of the rat after injection of $0.1 \mathrm{~mL}$ of $2 \% \mathrm{v} / \mathrm{v}$ formaldehyde is due to the release of histamine, serotonin, and the prostaglandin like substances at the site of injection [23]. Inhibition of paw edema in formaldehyde-induced arthritis may be due to the significant anti-inflammatory potential of HARE.

\section{CONCLUSION}

On the basis of the results obtained in this study, we conclude and propose that possibly, the potent anti-arthritic effect of aerial parts of hydroalcoholic HARE may be through maintenance of synovial membrane, thereby inhibiting cytokines and leukotriene infiltration inhibition as evidenced in paw edema volume. In turn, protecting synovial membrane and improving health status through anti-inflammatory properties of HARE. Improvement in health parameters considers in this study, including HB, ESR, and body weight indicating its beneficial effects while recovery from arthritis. From the results observed from the current investigation, it is concluded that the HARE possesses potent antiarthritic activity since it give a positive result in controlling inflammation in acute and chronic arthritic models in Wistar strain albino rats.

\section{ACKNOWLEDGMENTS}

The authors are thankful to Padmashree. Dr. M. Mohan Babu, Chairman, and Visionary, Sree Vidyanikethan Educational Trust. Principal and Management of Sree Vidyanikethan College of Pharmacy, Tirupati, for providing necessary infrastructure and facilities to conduct this research work.

\section{AUTHORS' CONTRIBUTIONS}

Ms. Radhika Chikatipalli Research scholar; conducted research work and consolidated results with discussion and conclusions.

Dr. K. Saravanakumar: Research supervisor; supervised the research work and guided to draft this research article as per the journal's instructions.

Dr. Chandra Sekhar Kothapalli Bonnoth: Research co-supervisor; supervised the research work and guided to draft this research article as per the journal's instructions.

\section{CONFLICTS OF INTEREST}

The authors have declared no conflicts of interest.

\section{AUTHORS' FUNDING}

This work is a part of self-funded part-time research program under the affiliation of Jawaharlal Nehru Technological University, Ananthapur.

\section{REFERENCES}

1. Harris ED. Rheumatoid arthritis. Pathophysiology and implications for therapy. N Engl J Med 1990;322:1277-89.

2. Boissier MC. Rheumatoid arthritis: Direct and indirect costs. Joint Bone Spine 2004;71:518-24.

3. Chaudhary BR. Guidelines for the management of rheumatoid arthritis. Am Coll Rheumatol Subcomm Arthritis Rheum 2002;46:328-46.

4. Ahmed S, Anuntiyo J, Charles J, Haqqi TM. Biological basis for the use of botanicals in osteoarthritis and rheumatoid arthritis: A review. Evid Based Complement Altern Med 2005;2:301-8.

5. Brunton LL, Lazo JS, Parker KL. Goodman \& Gilman's: The Pharmacological Basis of Therapeutics. $11^{\text {th }}$ ed. New York: McGrawHill; 2006.

6. Feldmann M, Steinman L. Design of effective immunotherapy for human autoimmunity. Nature 2005;435:612-9.

7. Arend WP, Dyer JM. Inhibition of the production and effects of interleukin-1 and tumor necrosis factor alpha in rheumatoid arthritis. Arthritis Rheum 1995;38:151-60

8. Feldmann M, Maini RN. Anti-TNF alpha therapy of rheumatoid arthritis: What have we learned? Annu Rev Immunol 2001;19:163-96.

9. Chitme HR, Patel NP. Antiarthritis activity of aristolochia bracteata extract in experimental animals. Open Nat Prod J 2009;2:6-15.

10. Baghai M, Osmon DR, Wolk DM, Wold LE, Haidukewych GJ, Matteson EL. Fatal sepsis in a patient with rheumatoid arthritis treated with etanercept. Mayo Clin Proc 2001;76:653-6.

11. Engel LW, Straus SE. Development of therapeutics: Opportunities within complementary and alternative medicine. Nat Rev Drug Discov 2002;1:229-37.

12. Jacobs JW, Rasker JJ, Bijlsma JW. Alternative medicine in rheumatology: Threat or challenge? Clin Exp Rheumatol 2001;19:117-9.

13. Kokate CK. Practical Pharmacognosy. $3^{\text {rd }}$ ed. New Delhi: Vallabh Prakashan; 1994. p. 107-11.

14. Lam FF, Wong HH, Ethel SK. Time course and substance P effects on the vascular and morphological changes in adjuvant-induced monoarthritic rats. Int Immunopharmacol 2004;4:299-310.

15. Butler SH, Godefroy F, Besson JM, Weil-Fugazza J. A limited arthritic model for chronic pain studies in the rat. Pain 1992;48:73-81.

16. Kauthale V, Kulkarni D, Chavan L, Patil S, Nalawade A. Diversity of wild edible plants in Dhadgaon block of Nandurbar District in Maharashtra, India. Int J Curr Res Biosci Plant Biol 2017;4:62-73.

17. Vedavathy S, Sudhakar A, Mrdula V. Tribal medicinal plants of Chittoor. Anc Sci Life 1997;16:307-31.

18. Mary AD, Franco FM, Babu V. Assessing the contribution of local and traded biodiversity in community health care: A case study from Keelakodankulam Village, South India. Ethnobot Res Appl 2011;9:275-86

19. Alves De Almeida AC, De-Faria FM, Dunder RJ, Manzo LP, Souza-Brito AR, Luiz-Ferreira A. Recent trends in pharmacological activity of alkaloids in animal colitis: Potential use for inflammatory bowel disease. Evid Based Complement Altern Med 2017;2017:1-24.

20. Nirmal SA, Ingale JM, Pattan SR, Bhawar SB. Amaranthus roxburghianus root extract in combination with piperine as a potential treatment of ulcerative colitis in mice. J Integr Med 2013;11:206-12.

21. Available from: http://www.ayushportal.nic.in/pdf/books/research $\% 20$ publications $\% 20$ in $\% 20$ ayurvedic $\% 20$ sciences.pdf.

22. Newbould BB. Chemotherapy of arthritis induced in rats by mycobacterial adjuvant. Br J Pharmacol Chemother 1963;21:127-36.

23. Bansod MS, Kagathara VG. Evaluation of analgesics and antiinflammatory activity of a poly-herbal formulation. Int J Pharm Tech Res 2010;2:1520-7.

24. Tripathy S, Pradhan D, Anjana M. Anti-inflammatory and antiarthritic potential of Ammania baccifera linn. Int J Pharm Bio Sci 2010;1:1-7. 